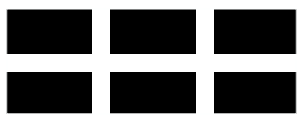

THE WILLIAM DAVIDSON INSTITUTE AT THE UNIVERSITY OF MICHIGAN BUSINESS SCHOOL

\title{
Why the Rich May Favor Poor Protection of Property Rights
}

\author{
By: Konstantin Sonin
}

William Davidson Working Paper Number 544

December 2002 


\title{
Why the Rich May Favor Poor Protection of Property Rights
}

\author{
Konstantin Sonin ${ }^{1}$ \\ New Economic School/CEFIR, CEPR, and WDI \\ First draft: June 30, 1998 \\ This draft: December 1, 2002
}

\begin{abstract}
In unequal societies, the rich might benefit from shaping economic institutions into their favor. This paper analyzes the dynamics of institutional subversion focusing on one particular institution, public protection of property rights. If this institution is imperfect, agents have incentives to invest in private protection of property rights. With economies of scale in private protection, rich agents have a significant advantage: they could expropriate other agents using their private protection capacities. Ability to maintain private protection system makes the rich natural opponents of full protection of property rights provided by the state. Such an environment does not allow grassroots demand to drive development of new market-friendly institutions (such as public protection of property rights). The economy as a whole is stuck in a 'bad' long-run equilibrium with low growth rate, high inequality, and wide-spread rent-seeking. The Russian 'oligarchs' of 1990s, a handful of politically powerful agents that controlled large stakes of newly privatized property, were the major motivation for this paper.
\end{abstract}

Keywords: economic institutions, property rights, political economy, inequality

JEL Codes: O1, P14, P26

\footnotetext{
${ }^{1}$ The author is grateful to Simeon Djankov, Do Quy-Toan, Richard Ericson, Jim Leitzel, Leonid Polishchuk, Victor Polterovich, Gerard Roland, Jacek Rostowski, and Judith Thornton for various helpful comments. Financial support of EERC-Russia is gratefully acknowledged. An earlier version of this paper has previously circulated as CEPR Discussion Paper 2300 "Inequality, Property Rights Protection, and Economic Growth in Transition Economies: Theory and Russian Evidence".
} 


\section{Introduction}

If the state does not protect economic agents from unlawful expropriation, they might do it themselves. One way to protect one's property is to maintain a private protection system, e.g., to hire a security firm or establish corrupt relationship with a public official. An alternative way for an agent is to reveal his preferences for more public protection of property rights through the political process, e.g., by voting for an appropriate candidate in a general election. In transition and developing economies, the latter option is often suppressed due to underdevelopment of political institutions. As a result, economic agents are forced to supplement their productive investment with investment in private protection. With economies of scale in private protection, rich agents have a significant advantage when operating in an environment with incomplete public protection of property rights. Furthermore, their ability to gain from redistribution due to improper protection of property rights makes them natural opponents of improvements in public protection.

The economy, where the rich support the regime of incomplete protection of property rights is an example of what Glaeser et al (2002) call 'subversion of institutions'. Rich agents can use their wealth and accumulated political power to shape the performance of economic institutions in their favor. Inequality encourages institutional subversion by the rich, which in turn leads to increased inequality. ${ }^{2}$ This paper focuses on dynamics of institutional choice: the political process determines the level of redistribution of wealth in the society, which in turn affects political choices of future generations.

One example of rapid institutional change is provided by transition economies, a "policy laboratory" for economists (Djankov and Murrel, 2002). The transition experience has shown that liberalization, macroeconomic stabilization, and de-jure privatization in a former command economy are not sufficient conditions for an upturn in economic activity. Among various explanations of the continued failure of some economies to achieve sustainable growth, the inability of the state to promote development of 'good' economic institutions and the unexpected stability of 'bad' ones is of particular interest. The goal of this paper is to provide micro- and political foundations for an environment, which does not allow grassroots demand for protection of property rights to drive development of new market-friendly institutions. In particular, we demonstrate that if the rich have enough political power to

\footnotetext{
${ }^{2}$ One limit to subversion of the property rights protection institution is that the beneficiaries of subversion still have to protect themselves from each other (Murphy et al, 1993).
} 
choose the level of public property rights protection, the economy could be locked in a stable long-run equilibrium with poor public protection of property rights.

The process of public enforcement and regulation of property rights by the state is influenced by social demands. Agents reveal their preferences over government policy through various political mechanisms. It is quite natural to expect that it is the rich agents who favor full protection of property rights. However, there is substantial evidence that in many countries rich agents are the main beneficiaries of poor protection of property rights, which allows them to gain from non-productive activities such as rent-seeking or any other redistributive activity through maintenance of expropriation capacities. In the absence of adequate public protection of property rights by the state, these rent-oriented structures (in modern Russia, their leaders are often referred to as 'oligarchs') might take control of a substantial share of the national economy. Usually, these structures combine productive activity with an extensive struggle for the rent-seeking pie. The oligarchs' success at rent-seeking makes it unsurprising that they prefer relatively poor protection of property rights. This in turn forces other economic agents to invest in private protection from expropriation. This may be the main reason why the Russian state has failed as yet to establish and enforce a clearly defined system of property rights.

It is by no means assumed that an agent investing in private protection of property rights invests necessarily in military capacities or such like. Rather, it may be investment in relational capital, e.g. in establishing corrupt relations with state authorities, costly relational contracting, or hiring a lawyer. In economic terms, it is a strategy of an economic agent to increase efficiency and predictability in his business relations. ${ }^{3}$ Since private protection capacities can be used to obtain various types of rents, we consider investment in private protections as a particular case of rent-seeking.

In the Tullock (1980) model of rent-seeking and in a great majority of other papers devoted to unproductive activities, agents compare their costs and benefits of participating in rent-seeking. In these models, agents usually have a clear choice of whether or not to participate in expropriation (or perhaps mix productive and appropriative activities). In our analysis, we assume that there can be no business without investment in private protection of property rights (e.g., Alexeev et al 1997; Leitzel, 1997). Then, as stressed in Shleifer (1997), the agents having private protection have incentives to expropriate resources

\footnotetext{
${ }^{3}$ Hendley, Murrell, and Ryterman (1998) analyze various types of such strategies of Russian enterprises.
} 
from others. This makes wide-spread private enforcement of property rights in transition economies inherently stable.

There are three basic types of negative consequences of poor protection of property rights for growth. First, the necessity to protect wastes resources as private protection (or any other kind of rent-seeking) is an unproductive activity. Second, the threat of expropriation distorts the economic environment and leads to suboptimal paths of capital accumulation and production. Third, extensive rent-seeking and improper public protection of property rights are usually associated with substantial income and wealth inequality. The impacts of inequality and redistribution policies on economic growth are well-studied. Alesina and Rodrik (1994), Persson and Tabellini (1994), and Benabou (1996) show, both theoretically and empirically, that inequality is harmful for growth. In these papers, and also in Perotti (1993), the poor are the beneficiaries of redistribution: such redistribution may occur through progressive taxation of capital income, direct social transfers, extensive regulation, trade and capital restrictions, etc. Persson and Tabellini (1994) assume that incomplete protection of property rights (through proportional tax on income) leads to redistribution of wealth from rich agents to poor. This paper departs from the growth-theory literature in assuming that the rich are beneficiaries of redistribution. ${ }^{4}$

The negative impact of poor protection of property rights on economic growth has been long stressed (e.g., Smith, 1776, North, 1981). Using an axiomatic approach, income distribution in a rent-seeking environment is studied in Hirshleifer (1991), Skaperdas (1992), and Skaperdas and Syropuolos (1997). In Grossman and Kim (1995), agents allocate real resources between appropriative and productive activities in a general equilibrium model. Spontaneous emergence of property rights have been studied by many authors. Gelb, Hilman, and Ursprung (1995) noted that in Russia ambiguous property rights provide prizes for rentseeking constests. Polishchuk and Savvateev (1997) modeled a one-shot rent-seeking game to favor rich agents at the expense of poor, and explored static general equilibria properties of the model. An empirical evidence on unofficial economy in transition is presented and extensively discussed in Johnson et al (1998). The political economy of partial reforms in transition economies with the emphasis on the role of powerful rent-seekers in keeping the

\footnotetext{
${ }^{4}$ In Acemoglu and Robinson (2000) the rich benefit from redistribution, but face a threat of revolution. Glaeser et al (2002) analyses the impact of inequality on subversion of capitalist institutions. Do (2002) focuses on the micromechanism which relates inequality and the extent of regulatory capture.
} 
economy in an intermediate ineffective state is discussed in Hellman (1998).

This paper contributes to the literature studying the interrelationship of inequality and institutional dynamics. The rich redistribute the wealth away from the poor, which leads to increased inequality, and thus more possibilities for the rich to gain from redistribution. Increased inequality may lead to more political demand for better institutions (higher level of property rights protection). If there is a significant wealth bias in the political system, the economy might be stuck in the long-run stable equilibrium, where these two forces (increasing inequality due to redistribution and decreasing level of redistribution due to increased inequality) offset each other.

The rest of the paper is organized as follows. In section 2, an endogenous growth model that allows to investigate the interrelationship between rent-seeking (private protection of property rights), inequality, and growth is introduced. Section 3 analyses the political economy of property rights protection. Section 4 contains a brief analysis of Russian oligarchs, who were the main motivating example for this paper, and presents evidence outside of transition economies. Section 5 concludes.

\section{Private Enforcement of Property Rights}

In this section, we employ a standard model of endogenous growth to analyze the impact of incomplete property rights on growth. In an overlapping-generations setup, agents choose the amount they invest in production and private protection.

\subsection{The Setup}

There is a continuum $[0,1]$ of heterogeneous overlapping-generations families. Each member $i$ born at the period $t$ has the utility function

$$
u_{i t}=\ln c_{i t}+\rho \ln d_{i t},
$$

where $c_{i t}$ is consumption when young, $d_{i t}$ is consumption when old, and $\rho$ is the common discount factor. This agent $i$ is born endowed with individual-specific basic level of skills $w_{i t}$. To simplify the subsequent analysis, it is assumed that the skills are distributed across agents log-normally:

$$
\ln w_{i t} \sim N\left(m, \sigma^{2}\right),
$$


and let $w_{t}$ denote the mean (and the aggregate) level of basic skills, where $w_{t}=E w_{i t}$. Intergenerational linkages are as follows:

$$
w_{i t+1}=\varepsilon_{i t+1} y_{i t},
$$

where $\varepsilon_{i t+1}$ is an i.i.d. shock with mean 1 and $\operatorname{Var}\left[\ln \varepsilon_{i t+1}\right]=\delta^{2}, y_{i t}$ is the second-period income of the member of family $i$ (to be defined later). ${ }^{5}$ Herein time indices are skipped as the analysis is focused on members of one generation.

Each agent $i$ has an access to a Cobb-Douglas technology, so that the second-period income is $y_{i}=A \widetilde{k}_{i}^{\beta} w^{1-\beta}$, where $\widetilde{k}_{i}$ is productive capital after redistribution, $A$ is an exogenously given technological parameter, and $w$ is the economy-wide endowment of basic skills. The $\widetilde{k}_{i}$ depends not only on the capital investment $k_{i}$ of the agent $i$, but also on investment of the agent $i$ into private protection of property rights, and both types of investment of other agents (see below). There are no credit markets, so agents have no possibility to borrow or lend to optimize consumption intertemporarily.

In addition to investment in production as described below, each agent may invest in protection of her property rights. If $k_{i}$ is the capital expenditures of the agent $i$, and $h_{i}$ is the amount invested in protection, then after redistribution the agent's $i$ productive capital is $\widetilde{k}_{i}=k_{i} h_{i}^{\theta} g$. So, for each individual agent production and private protection are strategic complements. The factor $g$ is defined by the balance condition

$$
\int_{0}^{1} \widetilde{k}_{i} d i=\int_{0}^{1} k_{i} h_{i}^{\theta} g d i=\int_{0}^{1} k_{i} d i .
$$

The parameter $\theta \geq 0$ measures the effectiveness of protection. The case $\theta=0$ then corresponds to full public protection of property rights. In this case, $h_{i}=0, g=1$, and no redistribution actually takes place. If $\theta>0$, then, given the redistribution technology, each agent invests some positive amount of capital in protection. The balance condition above shows that this investment is totally wasted. In Tullock (1980) words, there is a negative sum game.

\footnotetext{
${ }^{5}$ Technically, this setup is a familiar growth model (Persson and Tabellini, 1994, Verdier, 1994, Benabou, 1996). It allows to obtain closed-form solutions for maximization problems and thus greatly simplify exposition. At the same time, most of qualitative results remain the same in a much broader context, with an arbitrary non-degenerate distribution of wealth, different intra-generational linkages, and not necessarily multiplicative redistribution mechanism.
} 
The after-redistribution capital of the agent $i$ is

$$
\widetilde{k}_{i}=\frac{k_{i} h_{i}^{\theta}}{\int_{0}^{1} k_{i} h_{i}^{\theta} d i} \int_{0}^{1} k_{i} d i .
$$

This might be interpreted as a special form of a Tullock-type rent-seeking competition. Here contest inputs $h_{i}$ are weighted by the amount of capital invested, and the whole capital invested in production forms the rent-seeking pie. This type of redistribution possesses the basic features of rent-seeking: the relative success is a function of the parties' respective resource commitments. Precisely, the agent's proportionate share of the pie depends positively on her contest input and negatively on contest inputs of the others. The value of the prize, $\int_{0}^{1} k_{i} d i$, is endogenous variable as productive and appropriative capital are rival uses of resources (Hirshleifer, 1988 and Skaperdas, 1995). It is assumed, departing from the initial Tullock framework, that each agent takes $\int_{0}^{1} k_{i} h_{i}^{\theta} d i$ as given.

\subsection{Property Rights Protection and Growth}

Agent $i$ has the following maximization problem:

$$
\max _{k_{i}, h_{i}}\left\{\ln \left(w_{i}-k_{i}-h_{i}\right)+\rho \ln \left(A\left(\widetilde{k}_{i}\right)^{\beta} w^{1-\beta}\right)\right\} .
$$

A standard procedure gives the solution:

$$
k_{i}=p(\theta, \beta) w_{i}, \quad h_{i}=r(\theta, \beta) w_{i}
$$

where $p(\theta, \beta)$ and $r(\theta, \beta)$ are shares of the wealth agent $i$ invests in production and protection, respectively. Here investment in productive capital rises with improvement of property rights protection ( $\theta$ decreases) and productivity, $\beta: \frac{\partial}{\partial \theta} p(\theta, \beta)<0$ and $\frac{\partial}{\partial \beta} p(\theta, \beta)>0$. Investment in expropriation and thus welfare losses rise with $\theta$, i.e. $\frac{\partial}{\partial \theta} r(\theta, \beta)>0$. If property rights are fully secured, $\theta=0$, then $h_{i}=0$, and each agent splits his endowment between consumption and production.

Those agents that lose in redistribution overconsume in the first period, while those who gain underconsume compared to the case of $\theta=0$. That is, beside the dead-weight losses, rent-seeking distorts economic environment.

The second-period income of the agent $i$ is

$$
y_{i}=A p(\theta, \beta)^{\beta} w_{i}^{(1+\theta) \beta} \frac{w}{\left(E w_{i}^{1+\theta}\right)^{\beta}} .
$$


Summing over all agents, one can get an expression for the growth rate of the aggregate income:

$$
\gamma(\theta)=\ln (y / w)=\ln A+\beta \ln p(\theta, \beta)-\beta(1-\beta)(1+\theta)^{2} \frac{\sigma^{2}}{2} .
$$

With low level of property rights protection (high $\theta$ ), agents divert more resources from production to private protection of property rights. Proposition 1 summarizes the above discussion.

Proposition 1 Equilibrium consumption and investment in production of any agent increases with the level of property rights protection, while equilibrium in investment in private protection decreases. The growth rate of the economy increases with the level of property rights protection, and is maximized when property rights are fully secured, $\theta=0$.

Investing into private protection, agents do not internalize the impact of their actions on other agents' decisions: it increase incentives to invest into private protection and diminish incentives to invest into production. The negative effect of poor protection of property rights on growth comes from two sources: First, the lower is the level of property rights protection by the state (i.e. the higher is $\theta$ ), the more resources are devoted to private protection, a directly unproductive activity. Second, an increase in $\theta$ makes budget constraints more binding; this effect is reflected in the second term of the growth equation: in the absence of asset markets poor underinvest compared to the socially efficient level. Since the rich are the main beneficiaries of redistributive activity, inequality (as represented by $\sigma$ ) hampers productive investment and thus growth given any level of property rights protection $\theta$. If the capital market is perfect with the interest rate equal to the marginal product of productive capital, then the growth rate is $\gamma(\theta)=\ln A+\beta \ln p(\theta)$, and there is no second effect of incomplete protection of property rights as all the agents will invest the same amount of capital in production. Also, in this case inequality does not affect the growth rate. It is of course hard to imagine perfect capital markets in the absence of full protection of property rights. If we instead assume that loans and debts are subject for expropriation in the way described above, the results will be essentially the same.

\subsection{Why Is Manna so Harmful for Growth?}

Once a private protection system is maintained, it can be used to contest many types of rents at the same time. A related politician may help in establishing import tariffs in one industry 
and shaping regulation in another. As clearly demonstrated by the East Asia example (Claessens et al, 2000), oligarchs tend to have well-diversified businesses. We show that if, in addition to amending production, investment in private protection can be used to contest other rents, agents have more incentives to invest in private protection. The bigger the rent-seeking pie, the worse the situation is. Murphy, Shleifer, and Vishny (1993) emphasize that this might make rent-seeking self-generating. For example, when a foreign aid or loan is obtained, large rent-seekers may maintain their appropriative capacities to struggle for the pie, and then use the offensive weapons to appropriate resources from others. The same logic applies to many privatization cases. Further, where rent-seeking is allowed (public protection of property rights is poor), natural rents constitute an attractive pie. Gazprom, a natural gas monopoly, pays roughly a quarter of taxes collected by Russian government. In a developing country such as Mobutu's Zaire, natural rents may be an even greater as share of the country's GDP.

To model the effect of exogenous flow of rents to the economy, assume that, besides production and expropriation, an agent gains from 'pure' rent-seeking. The agent's $i$ share of the pie depends positively on her own investment in private protection (expropriation), $h_{i}$, and negatively on investment of the other agents. Specifically, it is assumed that the agent's $i$ productive capital after redistribution is $\widetilde{k}_{i}=k_{i} h_{i}^{\theta} g+\Delta \frac{h_{i}^{\theta} w_{i}}{H}$, where $\Delta$ is an exogenous rent-seeking pie, the multiplier $g$ is defined as above by the balance condition on the capital market, and $H=\int_{0}^{1} h_{i}^{\theta} d i$, the sum of contest inputs of all agents. Again, the rent-seeking technology favors rich: this is captured by the agent-specific constant $w_{i}{ }^{6}$ For the sake of simplicity, it is assumed that $\beta=1$, and therefore inequality do not play any role in the subsequent analysis, and also $\rho=1 .^{7}$ Thus, the agent's $i$ problem can be written as follows.

$$
\max _{k_{i}, h_{i} \geq 0, k_{i}+h_{i} \leq w_{i}}\left\{\ln \left(w_{i}-k_{i}-h_{i}\right)+\ln A \widetilde{k}_{i}\right\} .
$$

Solving the problem, one can obtain optimal investment in production and expropriation in the presence of exogenous rent:

$$
k_{i}=p(\theta, \Delta) w_{i}, \quad h_{i}=r(\theta, \Delta) w_{i} .
$$

\footnotetext{
${ }^{6}$ The qualitative results go through without such an assumption. This particular assumption allows to get a closed-form solution and greatly simplifies comparative statics.

${ }^{7}$ Main results below hold in a more general setup (e.g., for $\beta, \rho \neq 1$ ).
} 
If the pie, $\Delta$, is large enough, then the endowment, $w_{i}$, splits between consumption in the first period and investment in expropriation. In what follows, it is assumed that all solutions are interior. First, we observe that $\frac{\partial}{\partial \Delta} p(\theta, \Delta)<0$ and $\frac{\partial}{\partial \Delta} r(\theta, \Delta)>0$, i.e. the larger is the rent-seeking pie, the smaller is investment into production and the larger is the investment into private protection, which increase agent's proceeds from rent-seeking.

Proposition 2 The larger is the additional rent-seeking pie, $\Delta$, the lower is the growth rate $\gamma=\gamma(\theta, \Delta)$ of the economy.

\section{Political Economy of Redistribution}

The next goal is to determine the level of property rights protection preferred by agent $i$. Agent $i$ faces the following maximization problem:

$$
\max _{\theta \geq 0}\left\{u_{i}(\theta)=\ln (1-(p+r)) w_{i}+\rho \ln A p^{\beta} w_{i}^{(1+\theta) \beta} \frac{w}{\left(E w_{i}^{1+\theta}\right)^{\beta}}\right\} .
$$

It is easy to prove that any agent $i$ has single-peaked preferences over $\theta \geq 0$. This assures that the agent's $i$ problem has a unique solution, $\theta_{i}^{*}$. The poorer is the agent, the higher level of property rights protection she prefers. $^{8}$

Proposition 3 (i) If $w_{i} \geq w_{j}$, then $\theta_{i}^{*} \geq \theta_{j}^{*}$; that is, the richer the agent, the less secured property rights she prefers.

(ii) There exists a unique threshold $\bar{w}$ such that any agent $i$ with $w_{i} \leq \bar{w}$ prefers full protection of property rights, $\theta_{i}^{*}=0$, while any agent $i$ with $w_{i}>\bar{w}$ prefers incomplete protection of property rights, $\theta_{i}^{*}>0$.

In the recent rent-seeking literature, the level of property rights protection is often endogenous (e.g., Grossman and Kim, 1995). However, the nature of rent-seeking models leaves little chance that these models may be modified for the study of growth issues. Perotti (1993), Alesina and Rodrik (1994), Persson and Tabellini (1994), and Benabou (1996) have endogenized tax policy in the political equilibrium of endogenous-growth models. In this section,

\footnotetext{
${ }^{8}$ Polishchuk and Savvateev (1997) derive results similar to Proposition 2 in a static model, where production and rent-seeking are strategic substitutes. The basic intuition is that production process exhibits diminishing marginal returns, while returns to rent-seeking are constant.
} 
the next goal is to endogenize the level of property rights protection, as parametrized by $\theta$, in an analogous way. It is assumed that the old generation does not participate in the political process. The most straightforward approach is the use of the median-voter theorem (Grandmont, 1978). However, it is doubtful that transition economies satisfy the 'one person, one vote' ideal. Rather, anecdotal evidence suggests that the level of property rights protection (i.e. the actual performance of institutions) is determined by a relatively narrow group of powerful agents. Let the pivotal voter located at the $\pi^{\text {th }}$ percentile of the wealth (instead of usual $50^{t h}$ percentile). Then her wealth $w_{\pi}$ is defined by $\left.F\left(\left(\ln w_{\pi}-m\right) / \sigma\right)\right)=\pi$, where $F$ is the c.d.f. of a standard normal. One can reformulate this as follows: $\ln w_{\pi}=m+\lambda \sigma$, where $\lambda=F^{-1}(\pi)$. If $\lambda>0$, that is $\pi>\frac{1}{2}$, the political system is biased toward rich. Historically, this case corresponds to wealth-restricted franchise. Today, the bias toward rich might be due to their high lobbying power, imperfect political information, dependence on transfers from the central government in a transition economy, etc.

To investigate the effects of the wealth bias in the political system, substitute $\ln w_{\pi}=$ $m+\lambda \sigma$ into $u_{i}^{\prime}(\theta)=0$ for $w_{p} \geq \bar{w}\left(\lambda \geq \sigma+\frac{1}{\sigma}\right)$ and note that $\theta^{*}=0$ if $\lambda \leq \sigma+\frac{1}{\sigma}$.

Proposition 4 (i) The more democratic is the society (the lower is the degree of wealth bias of the pivotal voter, $\lambda$ ), the more secure are property rights in the political equilibrium (the lower is $\left.\theta^{*}\right)$. If $\lambda$ exceeds some threshold $\widetilde{\lambda}$ then $\theta^{*}$ strictly increases with $\lambda$.

(ii) For any pivotal voter, the higher is the productivity of production, $(\beta)$ or the more valuable is the future $(\rho)$, the more protection of property rights the pivotal voter prefers.

A straightforward corollary of (i) is that the political equilibrium leads to full public protection of property rights, $\theta=0$, if and only if $\lambda$ does not exceed some threshold. Increased inequality might reduce (for a wide range of parameters) the expropriation gains of the rich, and thus makes incomplete protection less attractive. This effect complicates the investigation of the impact of inequality on growth. While the direct effect of inequality on growth is negative, an increase in inequality forces the pivotal voter (who, all other things being equal, becomes poorer than before) to call for more secure property rights and favor more growth. The effect of a change in inequality on growth can be written down as

$$
\frac{d \gamma}{d \sigma}=\frac{\partial \gamma}{\partial \sigma}+\left.\frac{\partial \gamma}{\partial \theta}\right|_{\theta=\theta^{*}} \times \frac{\partial \theta^{*}}{\partial \sigma},
$$

where the first term on the right-hand side represents the direct effect of inequality on growth (holding policy, $\theta$, fixed), and the second represents the indirect one. If property rights are 
fully protected, then inequality affects growth exclusively through binding wealth constraints. In the above analysis, it was assumed that protection of property rights is provided by the state at zero cost, which is obviously not true. If agents bear costs of public protection, they prefer even less such protection, and thus the above results become even stronger.

Combining the solution to the maximization problem and intragenerational dynamics of income within a family gives the law of motion for the family's income:

$$
\ln w_{i t+1}=\ln \varepsilon_{i t+1}+\ln A+\beta \ln p+\left(1+\theta_{t}\right) \beta \ln w_{i}+\ln w-\beta\left(m\left(1+\theta_{t}\right)+\left(1+\theta_{t}\right)^{2} \frac{\sigma_{t}^{2}}{2}\right),
$$

where $\theta_{t}$ is the level of property rights protection chosen in period $t$. (Recall that $\theta_{t}$ is chosen by agents born at the period $t$.) Assuming $\operatorname{Var}\left[\ln \varepsilon_{i t+1}\right]=\delta^{2}$, one can get the autoregressive process for inequality:

$$
\sigma_{t+1}^{2}=\delta^{2}+\beta^{2}\left(1+\theta_{t}\right)^{2} \sigma_{t}^{2}
$$

Now a marginal reduction in the level of property rights protection increases not only the current inequality, but also inequality in all future periods.

Proposition 5 An increase in inequality leads (weakly) to a higher level of protection of property rights by the state. If there is a strong wealth bias in the political system, then there are multiple steady-states, with the 'bad' equilibrium characterized by high inequality and low level of property rights protection.

In Russia, income inequality has increased dramatically during transition (Kolenikov and Shorrocks, 2000). This might have increased the demand for public protection of property rights as discussed above. However, this does not mean that the economy eventually ends up with full protection. When a political system has a significant wealth bias, it may be locked in a long-run equilibrium with low level protection of public protection of property rights and low growth rate. As Hellman (1998) notes "the winners [of reforms] might have an implicit veto power in the decisions over separate components of reforms, especially those that affect their existing rent streams". A negative general equilibrium feedback of inequality on the level of property rights protection worsens budget constraints, and this effect allows to get multiple long-run steady states. The assumption of imperfect capital markets is crucial for this result: if agents are free to lend to and borrow from each other, their investment will always be socially optimal (given a level of property rights protection). 
The model above allows to get some implications about foreign direct investment to transition economies, which is widely believed to be an important determinant in succesful economic development. Brock (1997) found foreign direct investment in Russia (and other FSU countries) to be much lower than in East European transition economies, not to say about developed countries. Our analysis sheds some light on this phenomenon: First, investment in private protection is waste of resources for a foreign investor; second, in terms of the model above, the overall investment should be very large to allow for redistribution gains. Last but not least, such an investment (e.g., a bribe to a public official) may be considered illegal in the domestic country of the investor.

\subsection{King John vs. Robin Hood}

Glaeser et al (2002) call redistribution from poor to rich (our main case in this paper) the King John redistribution, and redistribution from rich to poor (such as progressive taxation or social security programs) the Robin Hood redistribution. Considering both types of redistribution brings some non-trivial insights. In particular, having a rich pivotal voter would help to offset efficiency losses in the case of excessive taxation.

Formally, suppose that there is a progressive tax on capital, with some tax rate $\tau$. Similar to Benabou (1996), it is assumed that redistribution is as follows. If the pre-tax capital is $k_{i}$, then the after-tax capital is $\widetilde{k}_{i}=k_{i}^{1-\tau} m^{\tau}$, where the multiplier $m$ is defined by the balance condition:

$$
\int_{0}^{1} \widehat{k}_{i} d i=\int_{0}^{1} k_{i}^{1-\tau} m^{\tau} d i=\int_{0}^{1} k_{i} d i .
$$

As before, incomplete protection of property rights also leads to some redistribution. The resulting $i$ 's capital stock is $\widetilde{k}_{i}$ with

$$
\int_{0}^{1} \widetilde{k}_{i} d i=\int_{0}^{1} \widehat{k}_{i}^{1-\tau} h_{i}^{\theta} g d i=\int_{0}^{1} \widehat{k}_{i} d i=\int_{0}^{1} k_{i} d i .
$$

For any $\theta$, the growth rate function exhibits usual properties: it is hill-shaped with respect to $\tau$, the tax rate (see Benabou, 1996 for full detail).

Proposition 6 For any tax rates $\tau>\tau^{\prime}$, there exists $\bar{\lambda}$ such that for any pivotal voter with $\lambda>\bar{\lambda}$, the preferred levels of protection of property rights satisfy $\theta^{*}(\tau)>\theta^{*}\left(\tau^{\prime}\right)$.

In words, if the tax rate is too high, then the pivotal voter (who need to be rich enough to loose from taxation) tries to offset the losses by lowering level of public protection of 
property rights. Polterovich (2001) obtains a similar result assuming that a fixed portion of the governments tax revenue is contested by economic agents.

This illustrates one particular difficulty a government faces: suppose that the tax rate is below the growth-maximizing tax rate. Now if the pivotal voter determining the level of property rights protection is rich enough, an increase of taxes would not lead to the desired increase of the growth rate. The reason is that following an increase in taxes, the level of property rights protection diminish. The impact through inequality would be fully offset, and the only remaining (negative) effect would be of increased taxes on incentives to invest in production. Vice-versa, if the tax rate is above the growth-maximizing rate, decreasing it would bring additional benefits of more secured property rights.

In most countries, the level of taxation (and, more generally, of redistribution toward poor) is usually determined by the legislative power (a chamber of representatives, say), while the level of property rights protection (the degree of subversion of the institution) is determined endogenously by various political actors. If the level of taxation (i.e. redistribution of capital toward poor) and the level of property rights protection (i.e. redistribution toward rich) are determined non-cooperatively by different pivotal voters, both of the parties fail to internalize the resulting losses. Intuitively, this is similar to the case of two authorities competing over one tax base by independently setting tax rates, a 'tragedy of commons'.

\subsection{Economic vs. Institutional Reforms}

The next goal is to show that a political base of economic reforms (defined broadly as measures to increase the tomorrow effectiveness at cost of the today consumption) narrows when protection of property rights is incomplete. Therefore, privatization, and any other economic reforms aimed to improve efficiency, are much less vulnerable for political opposition if it follows institutional reforms such as increasing protection of property rights by the state (Shleifer, 1997, Stiglitz, 2000). The intuition here is that with incomplete protection of property rights, an agent is not sure that he can successfully transfer a part of his endowment to the second period. An agent (that losses due to re-distribution) is less willing to sacrifice today consumption for an increase in efficiency tomorrow.

Formally, we illustrate this idea by presenting an economic reform as a trade-off between today's consumption and enhanced production tomorrow. Suppose that in the first-period agents consider paying a fixed share $\alpha$ of their first-period consumption for a next-period 
increase in production efficiency (that is, an increase in $\beta$ ). The reform is supported by agents, whose life-time utility increases.

Proposition 7 For large $\theta$ s, the share of agents supporting reform decreases with the level of property rights protection. The larger the inequality, the fewer voters support a reform.

\section{The Oligarchs}

Aristotle used the word 'oligarchy' ('power of the few' in Greek) to describe a political environment, where the rich rule for the own interests rather than those of the society. In modern times, this word has applied e.g. to the ruling elite in Imperial Japan (Ramseyer and Rosenbluth, 1995) and families possessing enormous economic power in Latin America (Dosal, 1995) and East Asia (Claessens et al, 2000).

Claessens et al (2000) reports that the largest ten families in Indonesia and the Philippines control more than half of the corporate assets $(57.7 \%$ and $52.5 \%$, respectively). The concentration of control in the hands of large families is also high in Thailand (46.2\%) and Hong Kong (32.1\%), Korea, Malaysia, and Singapore (25\%). ${ }^{9}$ Claessens et al (2000) conclude their analysis to say that "The concentration of corporate control in the hands of a few families creates powerful incentives and abilities to lobby government agencies and public officials for preferential treatment, whether through trade barriers, non-market-based financing, preferential public contracts, or other means. Concentration of control might also have been a detriment to the evolution of the countries legal systems."

The rule of oligarchy is often associated with poor protection of property rights. Johnson et al (2000) argue that the Asian financial crisis had more severe effects in countries with weaker investor protection (as measured by La Porta et al, 1997, 1998). One particular mean of redistribtion of wealth toward politically valuable agents are capital controls (Rajan and Zingales, 1998, 2002). Johnson and Mitton (2001) strongly support this view employing data Malaysian firms before and after the imposition of capital controls. In particular, they found that firms stock price performance in Malaysia is broadly supportive of the view that capital controls create a screen for cronyism.

\footnotetext{
${ }^{9}$ For comparison, in Japan, the largest 15 families controled only $2.1 \%$ of GDP in 1996; in USA this number was $2.9 \%$ of GDP in 1998.
} 
Transition experience provides another telling example. Glaeser and Shleifer (2002) use Russian oligarchs as an illustration to their subversion-of-institutions theory. At the beginning of the Russian transition, it was widely believed that institutional change, in particular development of the institutions of property rights, is best driven by grass-roots demand. ${ }^{10} \mathrm{In}$ an ideal world, it is the rich who favor full protection of property rights, since it is they who have most to lose in any re-distribution process. However, the reality appeared to be quite different. Russian 'oligarchs', a small group of politically influential people, that have taken command of a major share of Russia's productive assets, is a sound counterexample. Having accumulated enormous wealth and political power, they effectively blocked any attempts of the government to improve property rights protection (Polishchuk and Savvateev, 1997). Stiglitz (2002) says "Today, in Russia, we do not see demands for strong competition policy forthcoming from the oligarchs, the new monopolists."

There is a number of academic papers and books on Russian oligarchs, including Freeland (2000) and Hoffman (2002), which combine a detailed description of oligarchs' lives with political analysis. In this section, we collect some stylized facts about Russian oligarchs.

In the early years, rents for redistribution have arisen from various arbitrage opportunities, provided, e.g., by foreign trade liberalization with incomplete price liberalization, or privatization in the absence of credit markets, which allowed managers to use state-subsidized credits on short-term money markets (Barnes, 2002, Hellman, 1998). Later, oligarchs have extensively employed their political influence during the privatization in 1993-1996, ${ }^{11}$ and since then have been investing the capital obtained into extra-market redistribution (Polishchuk, 1995, Hoffman, 2002). For a large stake of the Svyazinvest, a major telecommunication holding in Russia, the parties employed newspapers, broadcasting programs (with no exception for shows and news programs), and officials of various ranks (with no exception for the Prime-minister, Ministers of Finance, and the Minister for Internal Affairs of Russia, see Freeland, 2000). During the political war, one of the parties (UNEXIM) announced the struggle for the establishment of rule of law, including the determination and enforcement of property rights. Stiglitz (2002) makes a general statement: "Demands for the rule of law have come from these oligarchs, who obtained their wealth through behind-the-scene deals

\footnotetext{
${ }^{10}$ Aslund (1995) argues that once "... the fundamental issues [of] the mutual independence of enterprises from one another (as well as from the state) and their profit orientation [have been addressed], under such conditions owners will forcefully try to ascertain their property rights".

${ }^{11}$ Boyko, Shleifer and Vishny (1995) is the main reference on Russian privatization.
} 
within the Kremlin, only as they have seen their special influence on Russia's rulers wane."

Before the Svyazinvest affair in 1997, the oligarchs rarely confronted each others as each of them had its own branch of the economy (e.g., mass-media for Most-bank, natural gas for Gazprom, international weapon trade for Rossiiskii Kredit, etc) and obtained rents from it (Freeland, 2000). To some extent, these holdings or financial-industrial groups has been formed within the process of rent-seeking, and thus can be indexed by the rents they receive. Enterprises which gain from natural or monopoly rents have been of particular interest for both Moscow financial groups and local strong men. Although the groups and their leaders had initially their business in different branches of economy, eventually all of them started to acquire businesses in unrelated fields, which have made their peaceful co-existence virtually impossible.

Among areas of common interest, mass-media have been of particular importance. During political wars, newspapers and broadcasting programs appeared to be an extremely effective mean of political influence and rent-seeking. Accumulation of media-related assets by an oligarch has lead to increasing political influence, and thus redistributive power. Sometimes investment into media has created additional social benefits: e.g., the extensive usage of broadcasting programs in rent-seeking has dramatically increased the quality of the overall broadcasting performance.

Most visible conflicts have arisen in the enterprises, where ambiguity in property rights allowed different parties to control parts of enterprises' cash flows. Forms of the struggle have been various, from an extensive murdering in Krasnoyarskii Aluminievyi Zavod to cumbersome legal schemes in Nizhnevartovskneftegaz (although there were also some murders). The latter (NNG) is a part of Tymenskaya Neftyanaya Kompania (TNK). The Alpha-group obtained a 40 percent of shares of TNK at an auction, and then struggled in arbitrage courts to get a control other NNG for two years. During this time, the management of NNG succeeded to sell all the property (including licenses) of NNG to newly created firms. Eventually, the Alpha-group took NNG under control, but has to fight for revision of decisions made by the previous management. This example represents a huge variety of problems connected with protection of rights of shareholders. Among an enterprises that are engaged in disputes with its shareholders are oil and electricity companies, including Vostochnaya Neftyanaya Kompaniya, Achinsky NPZ, AO Irkutskenergo, Sidanko, etc. ${ }^{12}$ Although protec-

\footnotetext{
${ }^{12}$ Freeland (2001) and Hoffman (2001) contain a handful of such examples.
} 
tion to shareholders against arbitrary dilution of ownership was granted by a presidential decree in August, 1995, many of western investors (especially those with small shares) have been struggling for recognition of their rights. In many case, it has been necessary to obtain a controlling interest in a company to get any access to information, which would have been accessible to any shareholder in a western economy (Berglof and van Thadden, 1999).

At the beginning of Russian transition, there were almost no productive capital in possession of economic agents (although some agents controlled remarkable parts of the state property). In this case, almost any profit-maximizing behavior included rent-seeking as an integral part. Agents faced the situation, in which they had to expropriate a part of budgetary means or divert a state enterprise's cash flows to start business, and then to seek for a budgetary financed consumers. Clearly, for Russian rent-seeking, the liberalization of economic activity prior to the privatization played an important role. It is conceivable that if the spontaneous privatization of financial flows would have been followed with a spontaneous privatization of capital assets, the situation with property rights protection at the later stages of transition might be better. However, the former process (privatization of capital assets) is necessarily much more observable than the latter (privatization of cash flows), and thus faces more public resistance. It is an illustration to the general fact that open forms of phenomena that has previously been hidden are associated with transition, although they are definitely not new.

Rent-seeking environment in today's Russia was to a large extent inherited from the Soviet economy. Under the former command system, property belonged to the state - in other words, to everybody in general and no-one in particular. In its late years, the Soviet economy represented a sort of a quasi-market economy. The operation of this economy included rent-seeking as an integral and important part. Indeed, the extensive struggle of expediters of state enterprises for scarce inputs, accompanied by wide-spread corruption, was a kind of rent-seeking. This activity had often been growth- promoting as it partially fulfilled the duties of the "invisible hand of market". At the same time, this way of economic behavior was harmful for future development as it promoted formation of the behavioral mores, in which private gain was founded mainly on distribution, and misallocation of the human capital in the economy. Interestingly, the idea to treat the Soviet economy as a rent-seeking society (Ekelund and Tollison, 1981), has not been yet recognized by a vast majority of Russian politicians, political scientists, and economists. Even now, restoration 
of the Soviet-type command system is often considered as measure to reduce or completely eliminate rent-seeking.

\section{Conclusion}

This paper addresses the issue of inequality and institutions. The channel adopted goes through directly unproductive, rent-seeking activities. Thus, the model provides insights in a much broader context than property rights protection: the model accommodates a theory of institutional choice. Indeed, assume that a social planner can freely choose the institutional parameter $\theta$, which has the same formal meaning as in the basic model, and that it translates into a cost $c(\theta)$, where $c(\theta)$ is decreasing and convex. We can interpret $\theta$ as the rigidity of the law: civil law would correspond to a low $\theta$ and a corresponding high efficiency loss, while common law would correspond to higher levels of $\theta$. The present model will predict that with high levels of inequality, when redistribution is important, it is optimal to choose higher levels of $\theta$ at the cost of efficiency. This modification emphasizes the trade-off between efficiency (which requires high levels of $\theta$ ) and subversion (which is mitigated when $\theta$ is low). With such an extension, the model provides a theory of institutional choice complimentary to Glaeser and Shleifer (2001, 2002) and Glaeser et al (2002), and documented by Djankov et al (2002).

The analysis clarifyes the mechanism underlying the negative influence of poor protection of property rights, and the political obstacles to full enforcement of property rights. Agents with no political power to appropriate privately the fruits of their efforts must devote substantial resources to the protection of their productive capital, and this reduces the attractiveness of production. In other words, the contestability of property rights diminishes the incentives to invest and accumulate capital. In theory, it can be easily seen that improvements in the field of property rights protection (both in the level and the effectiveness), and a reduction in the level of rent-seeking activity are preconditions for economic growth. Such improvements may occur only if they are in the self-interest of the majority of those who determine policy.

\section{References}


Acemoglu, D. and J. Robinson (2001) A Theory of Political Transitions, American Economic Review, 91, 4, 938-963.

Aslund, A. (1994) How Russia Became a Market Economy, Brookings Institution, Washington, D.C.

Alesina, A. and Rodrik, D. (1994) Distributive Politics and Economic Growth, Quarterly Journal of Economics, 109, 465-90.

Alexeev, M., Gaddy, C., and Leitzel, J. (1995) Economic Crime and Russian Reform, Journal of Institutional and Theoretical Economics, v.151(4), 677-692.

Barnes, A. (2002) Post-Soviet Russia as a Struggle for Property: Illuminating changes in the Russian political economy since 1998, mimeo.

Benabou, R. (1996) Inequality and Growth, NBER Macroeconomics Annual, MIT Press, 11-74.

Berglof, E. and von Thadden, E. (2000) Corporate Governance in Transition, mimeo.

Boyko, M., Shleifer, A. and Vishny, R. (1995) Privatizing Russia, MIT Press, Cambridge.

Brock, G. (1998) Foreign Direct Investment in Russia 1993-1995: Why So Little and Where Has it Gone, Economics of Transition, No. 5.

Djankov, S., La Porta, R., Lopez-de-Silanes, F., and Shleifer, A. (2002) Courts: The Lex Mundi Project, NBER Working Paper 8890.

Djankov, S. and Murrel, P. (2002) Enterprise Restructuring in Transition: A Quantitative Survey, Journal of Economic Literature, forthcoming.

Ekelund, R. and Tollison, R. (1981) Mercantilism as a Rent-Seeking Society, Texas A\&M University Press, College Station.

Freeland, C. (2000) The Sale of the Century, Crown Business, New York.

Frye, T. and Shleifer, A. (1997) The Invisible Hand and the Grabbing Hand, American Economic Review Papers and Proceedings, vol. 87, no.2, 354-58.

Frye, T. and Zhuravskaya, E. (1998) Private Protection and Public Goods: The Role of Regulation, Journal of Law, Economics, and Organization.

Glaeser, E., Scheinkman, J., and Shleifer, A. (2002) The Injustice of Inequality, Journal of Monetary Economics, forthcoming.

Grandmont, J.-M. (1978) Intermediate Preferences and Majority Rule, Econometrica, 46 (2), $317-30$.

Grossman, H. and Kim, M. (1995) Swords or Plowshares? A Theory of Security Claims to Property, Journal of Political Economy, 103, n. 6, 1275-88. 
Hellman, J. (1998) Winners Take All: The Politics of Partial Reform in Postcommunist Transitions, World Politics, 50.2, 203-34.

Hendley, K., Murrell, P., and Ryterman, R. (1998) Law, Relationships, and Private Enforcement: Transactional Strategies of Russian Enterprises, mimeo.

Hirshleifer, J. (1991) The Paradox of Power, Economics and Politics, 3(3), 177-200.

Hoffman, D.E. (2002) The Oligarchs: Wealth and Power in the New Russia, PublicAffairs, New York..

Johnson, S., Boone, P., Breach, A. and Friedman, R. (2000) Corporate Governance in the Asian Financial Crisis, 1997-98, Journal of Financial Economics 58, 141-186.

Johnson, S. and Mitton, T. (2001) Cronyism and Capital Controls: Evidence from Malaysia, mimeo.

Johnson, S., Kaufman, D., and Shleifer, A., (1998) The Unofficial Economy in Transition, Brookings Papers on Economic Activity, v. 2, 159-239.

Johnson, S., Kaufman, D., McMillan, J., and Woodruff, C. (1999a) Why Do Firms Hide? Bribes and Unofficial Activity After Communism, mimeo.

Johnson, S., McMillan, J., and Woodruff, C. (1999b) Contract Enforcement in Transition, mimeo.

Johnson, S., McMillan, J., and Woodruff, C. (2002) Property Rights and Finance, American Economic Review, forthcoming.

Johnson, S., McMillan, J., and Woodruff, C. (2000) Enterpreneurship and the Ordering of Institutional Reform: Poland, Slovakia, Romania, Russia and Ukraine Compared, Economics of Transition.

Kolenikov, S. and Shorrocks, A. (2000) Poverty trends in Russia during Transition, mimeo.

Li, D. (1996) A Theory of Ambigous Property Rights in Transition Economies: The Case of the Chinese Non-State Sector, Journal of Comparative Economics, 23, 1-19.

Murphy, K.M., Shleifer, A., and Vishny, R.W. (1993) Why Is Rent-Seeking So Costly to Growth? American Economic Review, v. 83, 409-14.

North, D. (1981) Structure and Change in Economic History, New York: Norton.

Perotti, P. (1993) Political Equilibrium, Income Distribution, and Growth: Theory and Evidence, Review of Economic Studies, vol. 60, 155-66.

Persson, T. and Tabellini, G. (1994) Is Inequality Harmful for Growth? American Economic Review, vol. 84, n. 3, 600-21.

Polishchuk, L. and Savvateev, A. (1997) Spontaneous Emergence of Property Rights: A Crit- 
ical Analysis, mimeo.

Polterovich, V. (2001) Rent-seeking, Tax Policy, and Economic Growth, NES mimeo.

Rajan, R. and Zingales, L. (1998) Which Capitalism? Lessons from the East Asian Crisis, Journal of Applied Corporate Finance 11, 40-48.

Rajan, R. and Zingales, L. (2002) The Great Reversals: The Politics of Financial Development in the 20th Century, manuscript MIT and Chicago.

Savvateev, A. (1998) Production and Rent-seeking Behavior, NES Working Paper.

Shleifer, A. (1997) Government in Transition, European Economic Review, 41 (3-5): 385-410.

Shleifer, A. and Vishny, R. (1993) Corruption, Quarterly Journal of Economics, 108, pp 60117.

Skaperdas, S. (1992) Cooperation, Conflict, and Power in the Absence of Property Rights, American Economic Review, v.82(4), 720-39.

Skaperdas, S. and Syropoulos, C. (1997) The Distribution of Income in the Presence of Appropriate Activities, Economica, v. 64, 101-17.

Smith, A. (1776) An Inquiry into the Nature and Causes of the Wealth of Nations, London.

Stiglitz, J. (2000) Whither Reform? mimeo.

Stiglitz, J. (2002) Globalization and Its Discontents, .

Verdier, T. (1994) Models of Political Economy of Growth: A Short Survey, European Economic Review, 38, pp 757-63. 


\section{William Davidson Institute Working Paper 544}

\section{Appendix}

\section{Proof of Proposition 1.}

The growth rate of the aggregate income is given by $\gamma(\theta)=\ln (y / w)=\ln A+\beta \ln s-\beta(1-$ $\beta)(1+\theta)^{2} \frac{\sigma^{2}}{2}$. If the level of property rights protection increases (i.e. $\theta$ becomes smaller), then $s(\theta)=$ $\frac{\rho \beta}{1+\rho \beta(1+\theta)}$, the share of capital devoted to production, increases, and the term $\beta(1-\beta)(1+\theta)^{2} \frac{\sigma^{2}}{2}$ that represents losses due to redistribution and inefficient resource allocation, decreases. Thus, the growth rate $\gamma(\theta)$ decreases with $\theta$. If $\theta=0$, there is no redistribution, and the growth rate is maximized, $\gamma(0)=\ln A+\beta \ln \frac{\rho \beta}{1+\rho \beta}-\beta(1-\beta) \frac{\sigma^{2}}{2}$.

Inequality enters the last term of the growth rate expression only. If $\sigma^{\prime 2}$ is larger, than the losses increase, since budget constraints (in the absence of complete financial markets) of agents become more binding.

\section{Proof of Proposition 2.}

Interior solutions are guaranteed if $\Delta \leq A e^{\theta \sigma^{2}} \min \left\{\frac{1}{1+\theta}, \frac{2}{\theta}, 1+\theta\right\}$. The first-order conditions are as follows: $\frac{1}{w_{i}-k_{i}-h_{i}}=\frac{A}{A k_{i}+\Delta w_{i} / H}$ and $h_{i}=\theta\left(w_{i}-k_{i}-h_{i}\right)$. Then

$$
k_{i}=\frac{1}{2+\theta}\left(1-\frac{\Delta(1+\theta)}{A e^{\theta \sigma^{2}}}\right) w_{i}=p(\theta, \Delta) w_{i}, \quad h_{i}=\frac{\theta}{2+\theta}\left(1+\frac{\Delta}{A e^{\theta \sigma^{2}}}\right) w_{i}=r(\theta, \Delta) w_{i},
$$

where the balance condition gives $g H=e^{\theta \sigma^{2}}$. Then the growth rate is given by

$$
\gamma=\ln (y / w)=\ln A+\ln \frac{1}{2+\theta}+\ln \left(1-\frac{\Delta(1+\theta)}{A e^{\theta \sigma^{2}}}\right) .
$$

Clearly, the growth rate $\gamma$ decreases with $\Delta$, and $\gamma$ is maximized when $\Delta=0$.

\section{Proof of Proposition 3.}

First, we shall prove that the function

$$
u_{i}(\theta)=\ln (1-(p+r)) w_{i}+\rho \ln A s^{\beta} w_{i}^{(1+\theta) \beta} \frac{w}{\left(E w_{i}^{1+\theta}\right)^{\beta}}
$$

is single-peaked for each $i$. For the maximization problem $\max _{\theta \geq 0} u_{i}(\theta)$, the first-order condition is $\frac{1+\rho \beta}{1+\rho \beta(1+\theta)}+\sigma^{2}(1+\theta)=\ln w_{i}-m$. Denote $\psi(\theta)=\frac{1+\rho \beta}{1+\rho \beta(1+\theta)}+\sigma^{2}(1+\theta)$, the left-hand side. Note that $\psi(0)=1+\sigma^{2}>0$. Taking the derivative, one gets $\psi^{\prime}(\theta)=\sigma^{2}-\frac{(1+\rho \beta) \rho \beta}{(1+\rho \beta(1+\theta))^{2}}$. Clearly, $\psi^{\prime \prime}(\theta)>0$ when $\theta \geq 0$, and by assumption $\left(\sigma^{2}>\frac{\rho \beta}{1+\rho \beta}\right) \psi^{\prime}(0)=\sigma^{2}-\frac{\rho \beta}{1+\rho \beta}>0$. This implies that $\psi^{\prime}(\theta)>0$ for all $\theta \geq 0$, whence $\psi(\theta)$ is an increasing function of $\theta \geq 0$. Therefore, the first-order condition $\psi(\theta)=\ln w_{i}-m$ has at most one $\operatorname{root} \bar{\theta} \geq 0$, and $u_{i}^{\prime}(\theta)>0$, if $0 \leq \theta<\bar{\theta}$ and $u_{i}^{\prime}(\theta)<0$, if $\bar{\theta}<\theta$. If there are no non-negative roots, i.e $\psi(0) \geq \ln w_{i}-m$, then $u_{i}^{\prime}(\theta)<0$ for all $\theta \geq 0$, and therefore, $\theta_{i}^{*}=0$. 
Now let $\bar{w}$ be such that $\ln \bar{w}=\ln w+1+\frac{\sigma^{2}}{2}$, where $w=E w_{i}=e^{m+\frac{\sigma^{2}}{2}}$.

(i) The possibility to have $\theta_{i}^{*}=\theta_{j}^{*}$, when $w_{i} \neq w_{j}$ arises when $w_{i} \leq \bar{w}$ as shown in (i). To show that if $w_{i}>\bar{w}$, then $\theta_{i}^{*}$ strictly increases with $w_{i}$, suppose that $w_{i}<w_{j}$, and note that $\theta_{i}^{*}$ and $\theta_{j}^{*}$ are roots of equations $\psi(\theta)=\ln w_{i}-m$ and $\psi(\theta)=\ln w_{j}-m$, respectively. Then $\psi\left(\theta_{i}^{*}\right)<$ $\psi\left(\theta_{j}^{*}\right)$, since $\psi$ is strictly increasing in $\theta$, and $\theta_{i}^{*}<\theta_{j}^{*}$ follows.

(ii) If $w_{i} \leq \bar{w}=e^{1+m+\sigma^{2}}$, then $\psi(0)=1+\sigma^{2} \geq \ln w_{i}-m$. Since $\psi^{\prime}(\theta)>0$ for all $\theta \geq 0$, $\theta_{i}^{*}=0$ as shown in the Proof of Lemma 1. If $w_{i}>\bar{w}$, then the equation $\psi(\theta)=\ln w_{i}-m$ has a positive root, $\theta_{i}^{*}$.

\section{Proof of Proposition 4.}

The level of property rights protection by the state is determined by the pivotal agent $\pi$ with $w_{\pi}$ such that $\ln w_{\pi}=m+\lambda \sigma$. Thus, the equilibrium level of protection, $\theta^{*}=\theta_{\pi}^{*}$, satisfies $\psi\left(\theta^{*}\right)=\ln w_{\pi}-m=\lambda \sigma$.

Since $\psi$ is strictly increasing in $\theta$, the lower is $\lambda$, the wealth bias, the lower is $\theta^{*}$, the equilibrium level of protection. (Lower $\theta^{*}$ corresponds to more protection.) Using Proposition 3, one gets that if $\lambda \sigma>1+\sigma^{2}$, then $\theta^{*}>0$. On the other hand, if $\lambda \sigma \leq 1+\sigma^{2}$, then $\theta^{*}=0$. Therefore, an agent with $\lambda=\sigma+\frac{1}{\sigma}$ is the wealthiest agent voting for full public protection of property rights.

\section{Proof of Proposition 5.}

If $\theta^{*}=0$, there is nothing to prove. Thus, it is assumed that $\theta^{*}>0$. The first-order condition for the level-of-protection maximization problem $\left(\max _{\theta \geq 0} u_{i}(\theta)\right)$ is as follows: $\frac{1+\rho \beta}{1+\rho \beta\left(1+\theta^{*}\right)}=\lambda \sigma-$ $\sigma^{2}\left(1+\theta^{*}\right)$. Note that the left-hand side does not depend on $\sigma$. If $\sigma^{2} \geq \frac{1}{2}$, then the right-hand side shifts down and becomes steeper when $\sigma$ increases. Thus, $\theta^{*}$ depends negatively on $\sigma$.

Now suppose that $\sigma^{2}<\frac{1}{2}$, i.e. $\sigma<\frac{1}{4}$. Consider some $\sigma<\sigma^{\prime}$, both less than $\frac{1}{4}$, and let $\theta^{*}=\theta^{*}(\sigma)$ and $\theta^{* \prime}=\theta^{*}\left(\sigma^{\prime}\right)$, respectively. First, we observe that if $\theta^{*} \geq \frac{\lambda}{\sigma+\sigma^{\prime}}-1$, then $\theta^{* \prime}<\theta^{*}$. Indeed, multiplying by $\left(\sigma^{\prime 2}-\sigma^{2}\right)$, one can rewrite the former inequality as $\left(\sigma^{\prime 2}-\sigma^{2}\right) \theta^{*} \geq \lambda\left(\sigma^{\prime}-\sigma\right)-$ $\left(\sigma^{\prime 2}-\sigma^{2}\right)$. Using $\frac{1+\rho \beta}{1+\rho \beta\left(1+\theta^{*}\right)}=\lambda \sigma-\sigma^{2}\left(1+\theta^{*}\right)$, one obtains $\frac{1+\rho \beta}{1+\rho \beta\left(1+\theta^{*}\right)}+\sigma^{\prime 2} \theta^{*} \geq \lambda \sigma^{\prime}-\sigma^{\prime 2}\left(1+\theta^{*}\right)$. Therefore, the line $f(\theta)=\lambda \sigma^{\prime}-\sigma^{\prime 2}(1+\theta)$ lies below the line $f(\theta)=\frac{1+\rho \beta}{1+\rho \beta\left(1+\theta^{*}\right)}+\sigma^{\prime 2} \theta^{*}-\sigma^{\prime 2} \theta$ (note that both lines have the same slope). Since $\frac{1+\rho \beta}{1+\rho \beta(1+\theta)}$ decreases with $\theta, \theta^{* \prime}<\theta^{*}$.

It remains to prove that $\theta^{*}=\theta^{*}(\sigma) \geq \frac{\lambda}{\sigma+\sigma^{\prime}}-1$. It is sufficient to show that $\theta^{*} \geq \frac{\lambda}{2 \sigma}-1$. From the first-order condition, one gets $\lambda \sigma<1+\sigma^{2}\left(1+\theta^{*}\right)$. It follows that $1+\theta^{*}>\frac{\lambda-1}{\sigma}$. Since $\sigma<\frac{1}{2}$, $\lambda>2 \sigma(\lambda-\sigma)$. Hence, $\frac{\lambda}{\sigma}>\frac{\lambda}{2 \sigma}+\lambda-\sigma>\frac{\lambda}{2 \sigma}+\frac{1}{\sigma}$ (the latter inequality follows from $\lambda \geq \sigma+\frac{1}{\sigma}$ ). Therefore, we proved that $\theta^{*} \geq \frac{\lambda}{2 \sigma}-1$ as claimed. 


\section{William Davidson Institute Working Paper 544}

There is a system of two equations that determines steady-states of the model:

$$
\left\{\begin{array}{c}
\sigma^{2}=\delta^{2}+\beta^{2}\left(1+\theta^{*}\right)^{2} \sigma^{2} \\
\frac{1+\rho \beta}{1+\rho \beta\left(1+\theta^{*}\right)}=\lambda \sigma-\sigma^{2}\left(1+\theta^{*}\right) .
\end{array}\right.
$$

Solving the first equation for $\left(1+\theta^{*}\right)=\frac{\sqrt{\sigma^{2}-\delta^{2}}}{\beta \sigma}$, we substitute the result into the second equation to get $\frac{1+\rho \beta}{1+\frac{\rho}{\sigma} \sqrt{\sigma^{2}-\delta^{2}}}=\lambda \sigma-\frac{\sigma}{\beta} \sqrt{\sigma^{2}-\delta^{2}}$, an equation in one variable. Rewrite it as follows: $\frac{1+\rho \beta}{1+\frac{\rho}{\sigma} \sqrt{\sigma^{2}-\delta^{2}}}+$ $\frac{\sigma}{\beta} \sqrt{\sigma^{2}-\delta^{2}}=\lambda \sigma$. It is straightforward to show that the left-hand side is an increasing concave function. Then there exists some $\bar{\lambda}$ such that for any $\lambda \geq \bar{\lambda}$, there are at least two steady-states.

\section{Proof of Proposition 6.}

In fact, Proposition 5 holds for all $\theta \geq 0$. The higher is the tax rate, the more equal is the after-tax distribution of wealth. Then Proposition 5 could be applied to show that a higher tax rate leads to a lower level of property rights protection.

\section{Proof of Proposition 7.}

Suppose that the reform requires each agent $i$ to pay the share of $\alpha$ for the increase in productivity from $\beta$ to $\beta^{\prime}$. Then the agent $i$ supports the reform as long as

$$
\beta^{\prime} \ln p\left(\theta, \beta^{\prime}\right)-\beta \ln p(\theta, \beta)+(1+\theta)\left(\beta^{\prime}-\beta\right) \ln \frac{w_{i}{ }^{1+\theta}}{E w_{i}^{1+\theta}}-\geq \ln (1-\alpha),
$$

or equivalently

$$
\frac{\beta^{\prime} \ln p\left(\theta, \beta^{\prime}\right)-\beta \ln p(\theta, \beta)}{\left(\beta^{\prime}-\beta\right)(1+\theta)^{2}}+\ln w_{i}-\left(m+(1+\theta) \frac{\sigma^{2}}{2}\right) \geq \frac{\ln (1-\alpha)}{\left(\beta^{\prime}-\beta\right)(1+\theta)^{2}} .
$$

From this equation, one can determine the threshold $\widetilde{w}=\widetilde{w}(\theta)$ such that any agent $i$ with $w_{i} \geq \widetilde{w}$ supports the reform. For large $\theta, \widetilde{w}(\theta)$ is a strictly increasing in $\theta$. 


\section{DAVIDSON INSTITUTE WORKING PAPER SERIES - Most Recent Papers}

The entire Working Paper Series may be downloaded free of charge at: www.wdi.bus.umich.edu

CURRENT AS OF 2/20/03

\begin{tabular}{|c|c|c|}
\hline Publication & Authors & Date \\
\hline No. 544: Why the Rich May Favor Poor Protection of Property Rights & Konstantin Sonin & Dec. 2002 \\
\hline $\begin{array}{l}\text { No. 543: Reinvested Earnings Bias, The "Five Percent" Rule and the } \\
\text { Interpretation of the Balance of Payments - With an Application to } \\
\text { Transition Economies }\end{array}$ & $\begin{array}{l}\text { Josef C. Brada and Vladimír } \\
\text { Tomšík }\end{array}$ & Feb. 2003 \\
\hline $\begin{array}{l}\text { No. 542: The Impact of Ownership Reform in Chinese Industry, 1995- } \\
2001\end{array}$ & $\begin{array}{l}\text { Gary H. Jefferson, Su Jian, Jiang } \\
\text { Yuan and Yu Xinhua }\end{array}$ & Feb. 2003 \\
\hline $\begin{array}{l}\text { No. 541: Defensive and Strategic Restructuring of Firms during the } \\
\text { Transition to a Market Economy }\end{array}$ & $\begin{array}{l}\text { Domadenik, Janez Prašnikar and } \\
\text { Jan Svejnar }\end{array}$ & Feb. 2003 \\
\hline No. 540: Tenuous Financial Stability & $\begin{array}{l}\text { Neven T. Valev and John A. } \\
\text { Carlson }\end{array}$ & Feb. 2003 \\
\hline $\begin{array}{l}\text { No. 539: Non-monetary Trade and Differential Access to Credit in the } \\
\text { Russian Transition }\end{array}$ & Vlad Ivanenko & Feb. 2003 \\
\hline $\begin{array}{l}\text { No. 538: International Price-Fixing Cartels and Developing Countries: } \\
\text { A Discussion of Effects and Policy Remedies }\end{array}$ & $\begin{array}{l}\text { Margaret Levenstein and Valerie } \\
\text { Suslow with Lynda Oswald }\end{array}$ & Feb. 2003 \\
\hline No. 537: Foreign Banks in Bulgaria, 1875-2002 & $\begin{array}{l}\text { Kenneth Koford and Adrian E. } \\
\text { Tschoegl }\end{array}$ & Jan. 2003 \\
\hline $\begin{array}{l}\text { No. 536: Forthcoming in Vanderbilt Journal of Transnational Law, } \\
\text { "Healthy Organizations and the Link to Peaceful Societies: Strategies } \\
\text { for Implementing Organizational Change" }\end{array}$ & $\begin{array}{l}\text { Jeannette Jackson and Maria } \\
\text { Coolican }\end{array}$ & Jan. 2003 \\
\hline $\begin{array}{l}\text { No. 535: Forthcoming in Vanderbilt Journal of Transnational Law, } \\
\text { "Workplace Violence and Security: Are there Lessons for } \\
\text { Peacemaking?" }\end{array}$ & $\begin{array}{l}\text { Frances E. Zollers and Elletta } \\
\text { Sangrey Callahan }\end{array}$ & Jan. 2003 \\
\hline $\begin{array}{l}\text { No. 534: Forthcoming in Vanderbilt Journal of Transnational Law, } \\
\text { "700 Families to Feed: The Challenge of Corporate Citizenship" }\end{array}$ & Tara J. Radin & Jan. 2003 \\
\hline $\begin{array}{l}\text { No. 533: Forthcoming in Vanderbilt Journal of Transnational Law, } \\
\text { "Governing for Genuine Profit" }\end{array}$ & Michael J. O'Hara & Jan. 2003 \\
\hline $\begin{array}{l}\text { No. 532: Forthcoming in Vanderbilt Journal of Transnational Law, } \\
\text { "Adapting Corporate Governance for Sustainable Peace" }\end{array}$ & $\begin{array}{l}\text { Timothy L. Fort and Cindy A. } \\
\text { Schipani }\end{array}$ & Jan. 2003 \\
\hline $\begin{array}{l}\text { No. 531: Forthcoming in Vanderbilt Journal of Transnational Law, } \\
\text { "Groundings of Voice in Employee Rights" }\end{array}$ & Dana Muir & Jan. 2003 \\
\hline $\begin{array}{l}\text { No. 530: Forthcoming in Vanderbilt Journal of Transnational Law, } \\
\text { Gender Voice and Correlations with Peace }\end{array}$ & $\begin{array}{l}\text { Morehead Dworkin and Cindy A. } \\
\text { Schipani }\end{array}$ & Jan. 2003 \\
\hline $\begin{array}{l}\text { No. 529: Forthcoming in Vanderbilt Journal of Transnational Law, } \\
\text { "The Organizational Model for Workplace Security" }\end{array}$ & Dr. Thomas K. Capozzoli & Jan. 2003 \\
\hline $\begin{array}{l}\text { No. 528: Forthcoming in Vanderbilt Journal of Transnational Law, } \\
\text { "Nationbuilding 101: Reductionism in Property, Liberty, and Corporate } \\
\text { Governance" }\end{array}$ & O. Lee Reed & Jan. 2003 \\
\hline $\begin{array}{l}\text { No. 527: Forthcoming in Vanderbilt Journal of Transnational Law, "On } \\
\text { Virtue and Peace: Creating a Workplace Where People Can Flourish" }\end{array}$ & $\begin{array}{l}\text { Caryn L. Beck-Dudley and } \\
\text { Steven H. Hanks }\end{array}$ & Jan. 2003 \\
\hline $\begin{array}{l}\text { No. 526: Forthcoming in Vanderbilt Journal of Transnational Law, } \\
\text { "Novartis and the United Nations Global Compact Initiative" }\end{array}$ & Lee A. Tavis & Dec. 2002 \\
\hline $\begin{array}{l}\text { No. 525: Why Transition Paths Differ: Russian and Chinese Enterprise } \\
\text { Performance Compared }\end{array}$ & Sumon Bhaumik and Saul Estrin & Jan. 2003 \\
\hline $\begin{array}{l}\text { No. 524: Official Regulations and the Shadow Economy: A Labour } \\
\text { Market Approach }\end{array}$ & Maxim Bouev & Dec. 2002 \\
\hline No. 523: Children at Risk: Infant and Child Health in Central Asia & Cynthia Buckley & Jan. 2003 \\
\hline No. 522: Wages and International Rent Sharing in Multinational Firms & $\begin{array}{l}\text { John W. Budd, Jozef Konings and } \\
\text { Matthew J. Slaughter }\end{array}$ & July 2002 \\
\hline $\begin{array}{l}\text { No. 521: Gross Job Flows in Ukraine: Size, Ownership and Trade } \\
\text { Effects }\end{array}$ & $\begin{array}{l}\text { Jozef Konings, Olga Kupets and } \\
\text { Hartmut Lehmann }\end{array}$ & Dec. 2002 \\
\hline $\begin{array}{l}\text { No. 520: Entrepreneurial Networking in China and Russia: Comparative } \\
\text { Analysis and Implications for Western Executives }\end{array}$ & Bat Batjargal & Dec. 2002 \\
\hline $\begin{array}{l}\text { No. 519: Agriculture and Income Distribution in Rural Vietnam under } \\
\text { Economic Reforms: A Tale of Two Regions }\end{array}$ & $\begin{array}{l}\text { Dwayne Benjamin and Loren } \\
\text { Brandt }\end{array}$ & Mar. 2002 \\
\hline
\end{tabular}

